\title{
Green IT Empowerment, Social Capital, Creativity and Innovation: A Case Study of Creative City, Bantul, Yogyakarta, Indonesia
}

\author{
Muafi \\ Universitas Pembangunan Nasional "Veteran" Yogyakarta (Indonesia) \\ muafi2013@gmail.com
}

Received: December 2014

Accepted: April 2015

\section{Abstract:}

Purpose: This study aims at analyzing the role of empowerment of Green Information Technology (IT) in Small Medium Entreprises (SMEs) and social capital of the creativity and innovation of creative SMEs in Bantul, Yogyakarta, Indonesia.

Design/methodology/approach: A statistical technique used in the present study was Partial Least Square. The primary data of the present research were obtained from questionnaires and interviews with some respondents. While secondary data were gained through the records and publications of related instances.

Findings: The research concluded that the empowerment of Green IT provides a significant role in creativity and innovation as well as social capital, and at the same time it also supplies a significant role in innovation.

Research limitations/implications: This study is proposed to fill the research gap and at the same time to emphasize the importance of the creative empowerment of SMEs in Indonesia in adopting Green IT and that they are not only ready to make use of Green IT. Green IT empowerment and social capital in the creative SMEs play an important function ingenerating of creativity and innovation in the Yogyakarta's creative SMEs. Creative industries which capitalize creative ideas and skills are expected to positively contribute to support the national economy. 
Practical implications: Creative SMEs grow and develop rapidly here and form clusters of creative industries in accordance with the resources of each cluster.

Originality/value: This paper is a first attempt to overlook the significant role of green IT empowerment in SMEs' rapid development in Yogyakarta, a growing province in economic sector in Indonesia. The result of the study is expected to lead other similar research which in the future will craft out the role of economic development and the use of environmental friendly material of production.

Keywords: empowerment of Green IT, social capital, creativity, innovation, environmental friendly

\section{Introduction}

The development of the creative industry sectors in Yogyakarta is expected to face the challenges of the Association of Southeast Asian Nations Economic Community (ASEAN Economic Community) 2015. Yogyakarta has a potency to maximize its creative industry sectors. It is seen from its potential human resources (HR) to develop the sector. Although it can be said that the raw material supply is still relatively limited (http://skalanews.com/berita/detail/188813/IndustriKreatif-DIY-Dinilai-Mampu-Hadapi-MEA).

Some Yogyakarta's creative SMEs have adopted information technology to manage their businesses, including the use of websites, email, phone, and fax (Muafi \& Roostika, 2014; Muafi, Gusaptono, Effendi \& Charibaldi, 2012a; Muafi, Wahyuningsih, Effendi \& Sriyono, 2012b; Muafi, 2012c; Achjari, Abdillah, Suryaningsum \& Supratman, 2010). Nevertheless, the use of information technology in SMEs in Indonesia, particularly Yogyakarta, is still limited to reports, product designs, internet access and presentation; andhence strategic activities have not yet widely used (Wahid \& Indarti, 2007; Muafi, et al., 2012a; Muafi \& Roostika, 2014; Sarosa, 2007). Researches show that the adoption of information technology among SMEs in Yogyakarta is still limited (Muafi, et al., 2012a; Handayaningsih \& Pujiono, 2009), especially in the implementation of Green IT awareness (Mariani \& Imam, 2012). The main obstacles in the implementation of Green IT in Indonesia are human resources, capital, and high investment (Yuniarti, 2012; Mariani \& Imam, 2012). Those are the constraints for the government, universities and the creative community, especially SMEs to participate in preparing and disseminating the use of Green IT in the future. Green IT model readiness has been observed by several researchers and yet they still focus on using green IT readiness viewed from the aspect of attitude, policy, practice, technology, governance (Molla, Cooper, Corbitt \& Deng, 2008; Tenhunen, 2011; Mariani \& Imam, 2012, Yuniarti, 2012) and ICT personnel (Wadwoba, Wanyembi, Omuterema \& Omieno, 2013; Fors \& Lennerfors, 2013). 
Molla et al. research (2008) emphasized that the understanding and the influence of Green IT is a business with a sustainable performance. Principles, practices, and values of Green IT can make a major pillar of e-readiness framework to help organizations evaluate their readiness to adopt Green IT. Without any preparation, the Green IT approach would only turn out to be reactive and create an ad-hoc policy. Tenhunen (2011) examined the adoption of Green IT in Finland by using attitude measurements, paperless office, management, and virtualization. The results suggested that the four variables have an influence on the adoption of Green IT. Several companies have introduced the concept and activities related to Green IT. But the mechanical repairs and paperless office activities being executed do not show any importance to environmental reasons. In Indonesia, Green IT research shows that organizations surveyed did not have sufficient capability of the readiness to implement Green IT. Green IT is actually expected to encourage a reduction in operating costs (Mariani \& Imam, 2012). However, Yuniarti's results (2012) concluded that in general the five respondents in the manufacturing industry have a positive attitude even though the indicators are gaining attention because of the negative attitude of the respondents is on policy and governance indicators despite Wadwoba et al. research results (2013) which proved that IT personnel is also important for the adoption of Green IT. Likewise, research results from Fors and Lennerfors (2013) on HR aspects, namely the owner, partner organizations, and customers are necessary to have if the organization wants to conduct an audit of Green IT.

This study is proposed to fill the research gap and at the same time to emphasize the importance of the creative empowerment of SMEs in Indonesia in adopting Green IT and that they are not only ready to make use of Green IT. Aspects of empowerment and social capital are interrelated to each other and they are very important in the implementation of Green IT, especially in creative and innovative behaviors (Wahyuningsih, Muafi \& Roostika, 2014; Çekmecelioğlu \& Özbağ, 2014; Cekmecelioglu \& Gunsel, 2013; Seibert, Wang \& Coutright, 2011; Mawardi, 2007).

\section{Theory and Hypothesis}

\subsection{Green IT: Definition, Motivation and Focus Area}

Business enterprise, government, and association are now very focused on the importance of Green Economy. The concept of Green IT or ICT is not clearly defined yet. Yet the definition from the following two experts can provide an understanding of the Green IT concept and its impact on a sustainable business performance and environment. 
Murugesan (2008: pages 25-26) found that.

"Green IT refers to environmentally sound IT. It's the study and practice of designing, manufacturing, using, and disposing of computers, servers, and associated subsystems -such as monitors, printers, storage devices, and networking and communications systems-efficiently and effectively with minimal or no impact on the environment. Green IT also strives to achieve economic viability and improved system performance and use, while abiding by our social and ethical responsibilities. Thus, green IT includes the dimensions of environmental sustainability, the economics of energy efficiency, and the total cost of ownership, which includes the cost of disposal and recycling".

Molla, Cooper and Pittayachawan (2009: page 4) and Tenhunen (2011: page 6) added that.

Green IT is a systematic application of environmental sustainability criteria to the design, production, sourcing, use and disposal of the IT technical infrastructure as well as within the human and managerial components of the IT infrastructure in order to reduce $I T$, business process and supply chain related emissions and waste and improve energy efficiency."

Two of these definitions provide an understanding that the adoption of Green IT is important in the management of business organizations. Ozturk, Umit, Medeni, Ucuncu, Caylan, Akba et al. (2011) explained that some studies from academics and practitioners have also been growing rapidly. Ozturk et al. (2011) confirmed the Mines's opinion (2008) who found that Greet IT services market has actually grown rapidly, almost $\$ 5$ billion in 2013. Pasca 2013, the market will decline as most companies will have completed their initial round of green IT implementations. According to Tenhunen (2011), there are three types of motivations for companies to go green. Green solutions can be categorized for example as risk management, seeking business opportunities and so called goodwill and responsibility to the society and environment (Tenhunen, 2011). The impact of each of motivation will still give a positive contribution to both the organization and the individual (Tenhunen, 2011; Murugesan, 2008). More details can be seen in Table 1. 


\begin{tabular}{|l|l|l|l|}
\hline \multicolumn{1}{|c|}{ Type of motivation } & \multicolumn{1}{|c|}{ Description } & \multicolumn{1}{c|}{ Effect } \\
\hline $\begin{array}{l}\text { Environmental risk } \\
\text { management }\end{array}$ & $\begin{array}{l}\text { Aligning business activities } \\
\text { with current and } \\
\text { forthcoming rules and } \\
\text { regulations }\end{array}$ & $\begin{array}{l}\text { Reduce operational and } \\
\text { financial risks }\end{array}$ & $\begin{array}{l}\text { Energy efficient data center } \\
\text { operations help cut } \\
\text { emissions and energy bill }\end{array}$ \\
\hline Upside benefits & $\begin{array}{l}\text { Inovations and business } \\
\text { opportunities that 'improve } \\
\text { long term profitabilty' }\end{array}$ & $\begin{array}{l}\text { - Potential higher } \\
\text { revenues, lower costs } \\
\text { Attract investors } \\
\text { Intangible benefits: } \\
\text { brand loyalty and } \\
\text { employee satisfaction }\end{array}$ & $\begin{array}{l}\text { - Use of IT to develop new } \\
\text { renewable energy } \\
\text { solutions } \\
\text { Active participation in } \\
\text { developing } \\
\text { environmentally friendly } \\
\text { regulatory environment } \\
\text { for electronics }\end{array}$ \\
\hline Environmental stewardship & "Doing the right thing" & $\begin{array}{l}\text { Putting effort to } \\
\text { environmental } \\
\text { responsibility especially in } \\
\text { regard to a firm's core } \\
\text { business benefits both } \\
\text { stockholders and } \\
\text { stakeholders }\end{array}$ & $\begin{array}{l}\text { Green IT and financial } \\
\text { benefits are often aligned }\end{array}$ \\
\hline
\end{tabular}

Table 1. Motivations behind environmental responsibility (Tenhunen, 2011: page 13)

Furthermore, Murugesan's opinion (2008: pages 25-26) explains that Green IT spans a number of focus areas and activities, including: design for environmental sustainability; energy-efficient computing; power management; data center design, layout, and location; server virtualization; responsible disposal and recycling; regulatory compliance; green metrics, assessment tools, and methodology; environment-related risk mitigation; use of renewable energy sources; and eco-labeling of IT products. In a more comprehensive holistic view, environment has an impact on IT. According to Murugesan (2008: pages 25-26), there are four components that can be used as a guide:

1. Green use. Reduce the energy consumption of computers and other information systems and use them in an environmentally sound manner.

2. Green disposal. Refurbish and reuse old computers and properly recycle unwanted computers and other electronic equipment.

3. Green design. Design energy efficient and environmentally sound components, computers, servers, and cooling equipment.

4. Green manufacturing. Manufacture electronic components, computers, and other associated subsystems with minimal or no impact on the environment.

Therefore, by focusing on those four components, companies should be able to achieve a sustainable business performance and environment. 


\subsection{Empowerment, Creativity and Innovation}

A management consultant and an author W. Alan Randolph, in one hand, defines that "... empowerment is recognizing and releasing into the organization the power that people already have in Reviews their wealth of useful knowledge, experience and internal motivation"', (Kreitner \& Kinicki, 2003). On the other hand, Parkins and Zimerman (1995) says that,

"...empowerment is the construct that links individual strengths and competencies, natural helping systems, and proactive behaviors to social policy and social change. Empowerment theory, research, and intervention individual links well being with the larger social and political environment. Enhance wellness oriented empowerment interventions also while they aim to ameliorate problems, provide opportunities for Americans of participants to develop knowledge and skills, and engage professionals as collaborators instead of authoritative experts".

The above statement approves that empowerment has a very good purpose that is to develope businesses and while at the same time to implement green IT, so that they will be more creative and innovative. In Indonesia, according to decree No. 20 of 2008 which explains that the purpose of empowering SMEs are: (a) to realize the national economic structure which is said to be in balance, well growth, and justice, (b) to foster and develop the capabilities of SMEs to be strong and independent businesses, and; (c) to enhance the role of SMEs in regional development, job creation, income generation, economic growth and poverty alleviation of the people. Yogyakarta's creative SMEs seem to have realized the abundant and relatively in expensive cost of potential natural and human resources. In the future, those potencies are very important because many creative SMEs rely on the availability of efficient resources and creativity.

Empowerment of SMEs in Indonesia is required to protect and to prevent the incompatible goals and competitions among SMEs. It is also expected to develop a partnership between the communities and to create good relationship among SMEs. Empowerment of SMEs can be done through; (a) revitalizing and strengthening the position of SMEs in the national economic system, (b) revitalizing the corporations and strengthening SMEs by improving their access to capital, technology, information and markets, and the improvement of business climate as well, (c) optimizing the use of resources and development, and (d) developing the potency of local resources. Some researches explain that empowerment has a positive relationship with outcomes such as job satisfaction, organizational commitment, task performance, and contextual performance. On the other hand, an empowerment has negatively related to employee empowerment strain and turnover intention (Seibert et al., 2011). The findings differ from what Çekmecelioğlu and Özbağ (2014) has said that the empowerment of psychology will give a positive influence on one's creativity. Someone can be said to be creative and proactive 
because his organization empowers are cultivates him well. It is the fact that creativity effects innovation.

Similar conclusion was also delivered by Çekmecelioğlu and Gunsel (2013) that a creative individual who works in a creative working environment will affect the innovation of either individual or in groups within an organization. Creativity and innovation are important for SMEs because creativity is the process of finding and innovation is the practice of management. Individual creativity is often considered as a critical component to facilitate organizational innovation (Scott, 1965; Amabile, 1988). In the future, it is expected that individual or organizational creativity will increase the long-term success and sustainability of the organization (Tushman \& O'Reilly, 1997), and the company's competitive advantage (Hunt \& Morgan, 1995).

H1. Empowerment of Green IT toward the doers of creative SMES positively significant effect on creativity.

H2. Creativity of the doers of creative SMEs positively significant effect on innovation.

\subsection{Social Capital and Innovation}

Mawardi (2007) states that in the implementation of empowerment in Indonesia, there will be a close relationship between a local social capital such as institution, local knowledge, norms and local customs. Bourdieu (1983) defines that, "Social capital is the aggregate of the actual or potential resources which are linked to possession of a durable network of more or less institutionalized relationships of mutual acquaintance and recognition". The relationship between SMEs with economic institutions will be closely linked to social capital owned by an individual or an organization (Nahapiet \& Ghoshal, 1998), and is useful to expand the network that has a reciprocal relationship with individuals and between groups within the organization (Baron \& Hannan, 1994). Social capital focuses on the relationship between individual networks, mutual trust and the existence of norms that regulate the cooperation networks (Putnam, 1995).

Meanwhile, Muafi et al. (2012b) reported that when doing business incubation in creative SMEs in Bantul, Yogyakarta, it is found out that social capital (called "paguyuban") is needed in the development of SMEs' businesses. This association may provide benefits in market information, access to capital, training and mentoring, exhibition information, prices and similar normsetting which are useful for group progress. This is in line with the opinion of Grootaert and Bastelaer (2001) and also Woolcock and Narayan (2000) that friends and colleagues, or people who enter into any organization will share each other's problem regardless of how well they know each other. Camps and Marques (2011) findings concluded that social capital can increase organizational innovation capabilities. Kassa (2007) even found that social capital has 
a strong influence on the activity of innovation. Social capital is measured with different dimensions so that it gives different effect on innovation. In the other way around, Akçomak and Weel (2008) found out that social capital cannot accelerate the growth of income percapita in the EU.

H3. Social capitals possessed by creative SMES will positively significant effect on innovation.

\section{Research Methods}

The study was conducted on creative SMEs in Bantul, Yogyakarta Province. From each district chosen in the province, there were two selected villages that are relatively homogeneous and have the largest business units which show the same characteristic of creative SMEs. The population in this study is all creative SMEs in Bantul, Yogyakarta. To determine the selected districts, purposive sampling method is used to denote the highest number of creative SMEs from each district. This study used quantitative analysis approach adopting Partial Least Square (PLS) techniques. The reason of using PLS is that it is a powerful technique that can serve as a tool to analyze the latent variables in structural equation models with a variety of indicators. Another reason is that PLS does not require normally distributed data (Muafi \& Roostika, 2014). Primary data of the research were the questionnaires that have been given directly to respondents and the interviews with some of doers. Meanwhile, the secondary data were collected from several publications of local government and business magazines. Questionnaires were administered from 130, and the respondents who answered the quessionaires completely were 102 respondents (response rate of $78 \%$ ). The technique used to measure the empowerment of Green IT, social capital, creativity and innovation was Likert scale which has five alternative answers: 1 . Strongly Disagree (SD) to 5 . Strongly Agree (SA). The number of each variable denoted that the empowerment of Green IT includes 5 items, social capital includes 4 items, creativity includes 5 items, and innovation includes 7 items. The results of validity and reliability tests on all of test' items and variables showed that they are valid and reliable. 


\section{Results}

\subsection{Descriptive Data}

Data from valid 102 respondents' response is shown in Table 2. The descriptions for respondents' characteristics analyzed in this research were based on respondents' status, type of business, company's age, number of employees, and IT functions. The respondents in this research mostly work on handicraft businesses (32 respondents $-31 \%$ ), with less than 5 years of age (45 SMEs - 44\%), having a number of employees less than 50 people (76 SMEs $75 \%$ ), and using IT to type their reports (56 SMEs - 55\%).

\begin{tabular}{|l|c|c|}
\hline Respondents' Characteristics & Amount & Percentage \\
\hline Business Type & & \\
Advertising & 9 & 9 \\
Handicraft & 32 & 31 \\
Fashion & 8 & 8 \\
Printing \& Publishing & 9 & 9 \\
Architecture & 11 & 11 \\
Design & 10 & 10 \\
Antique Goods & 12 & 12 \\
Others & 11 & 11 \\
\hline Age of Company & & \\
<5 Years & 45 & 44 \\
5 - 10 Years & 34 & 33 \\
$11-15$ Years & 10 & 10 \\
> 15 - 20 Years & 9 & 9 \\
> 20 Years & 4 & 4 \\
\hline Number of Employees & & \\
< 50 people & 76 & 75 \\
51 - 100 people & 18 & 18 \\
> 100 - 500 people & 8 & 8 \\
\hline IT Utilization & & \\
Typing Reports & 56 & 55 \\
Designing Products & 22 & 22 \\
Accessing Internet & 9 & 100 \\
Presentation & 5 & \\
Others & 102 & \\
\hline Totals & & \\
\hline
\end{tabular}

Table 2. Respondents' Characteristics 


\subsection{Validity and Reliability Test}

The validity of the model was evaluated by the discriminant validity values and indicator's convergent.

\subsubsection{Discriminant Validity Index}

Discriminant validity index was measured by doing cross loading and using a comparison on the correlation of the square root of Average Variance Extracted (AVE) towards latent constructs. The discriminant validity index from the cross loading factors can be seen in Table 3.

\begin{tabular}{|c|c|c|c|c|}
\hline & Creativity & $\begin{array}{c}\text { Green IT } \\
\text { Empowerment }\end{array}$ & Innovation & Social Capital \\
\hline I1 & 0.531 & 0.318 & 0.758 & 0.457 \\
\hline I2 & 0.539 & 0.305 & 0.813 & 0.614 \\
\hline I3 & 0.445 & 0.297 & 0.642 & 0.535 \\
\hline I4 & 0.427 & 0.268 & 0.642 & 0.364 \\
\hline I5 & 0.424 & 0.357 & 0.698 & 0.375 \\
\hline I6 & 0.401 & 0.318 & 0.690 & 0.351 \\
\hline I7 & 0.506 & 0.424 & 0.670 & 0.439 \\
\hline $\mathrm{C} 1$ & 0.788 & 0.518 & 0.544 & 0.681 \\
\hline $\mathrm{C} 2$ & 0.827 & 0.624 & 0.478 & 0.467 \\
\hline $\mathrm{C} 3$ & 0.730 & 0.570 & 0.635 & 0.496 \\
\hline $\mathrm{C} 4$ & 0.774 & 0.401 & 0.469 & 0.440 \\
\hline $\mathrm{C} 5$ & 0.710 & 0.509 & 0.404 & 0.446 \\
\hline $\mathrm{SC} 1$ & 0.469 & 0.420 & 0.591 & 0.761 \\
\hline $\mathrm{SC} 2$ & 0.491 & 0.464 & 0.428 & 0.766 \\
\hline $\mathrm{SC} 3$ & 0.552 & 0.450 & 0.522 & 0.809 \\
\hline SC4 & 0.540 & 0.478 & 0.420 & 0.732 \\
\hline $\mathrm{E} 1$ & 0.558 & 0.776 & 0.285 & 0.531 \\
\hline E2 & 0.628 & 0.853 & 0.450 & 0.560 \\
\hline E3 & 0.515 & 0.834 & 0.279 & 0.400 \\
\hline E4 & 0.523 & 0.782 & 0.308 & 0.381 \\
\hline E5 & 0.562 & 0.790 & 0.523 & 0.470 \\
\hline
\end{tabular}

Table 3. The cross loading 
Chin (1998) recommends that all item loadings should not be less than 0.5. By looking at the cross loading values, it seems clear that the loading item value of each construct has a greater value than that of the other constructs' loading indicators. Whereas, the discriminant validity index from the correlation value of the square root of AVE towards latent constructs can be seen in Table 4.

\begin{tabular}{|l|c|c|c|c|}
\hline & Creativity & $\begin{array}{c}\text { Green IT } \\
\text { Empowerment }\end{array}$ & Innovation & Social Capital \\
\hline Creativitv & $\mathbf{0 . 7 6 7}$ & & & \\
\hline Green IT Empowerment & 0.693 & $\mathbf{0 . 8 0 8}$ & & \\
\hline Innovation & 0.670 & 0.462 & $\mathbf{0 . 7 0 4}$ & \\
\hline Social Capital & 0.665 & 0.585 & 0.651 & $\mathbf{0 . 7 6 8}$ \\
\hline
\end{tabular}

Table 4. Correlation of the square root of AVE

Based on Table 4, it can be seen that the value AVE is higher than the correlation between other variables, which indicates that the variables are said to have a good discriminant validity. Based on the result of the discriminant validity test using cross loading and a comparison on the correlation of the square root of AVE between other variables, it showed that the variables in this study had a good discriminant validity index.

\subsubsection{Convergent Validity}

Convergent validity of the measurement model with a reflexive indicator has a value based on the correlation between item score and construct score. Convergent validity index was measured by AVE, communality, and loading factors. The index result of AVE and communality can be seen in Table 5.

\begin{tabular}{|l|c|c|}
\hline & AVE & Communality \\
\hline Creativitv (C) & 0.588 & 0.588 \\
\hline Green IT Empowerment (E) & 0.652 & 0.652 \\
\hline Innovation (I) & 0.500 & 0.500 \\
\hline Social Cadital(SC) & 0.589 & 0.589 \\
\hline
\end{tabular}

Table 5. AVE and communality 
Based on Table 5, it can be seen that the values of AVE and communality variable creativity, green IT empowerment and social capital are greater than 0.5, which indicates that these variables have a good convergent validity value. Whereas convergent validity index measured by the value of loading factors can be seen in Table 6 .

\begin{tabular}{|c|c|c|c|c|c|c|}
\hline & $\begin{array}{c}\text { Original } \\
\text { Sample (0) }\end{array}$ & $\begin{array}{l}\text { Sample } \\
\text { Mean (M) }\end{array}$ & $\begin{array}{l}\text { Standard } \\
\text { Deviation } \\
\text { (STDEV) }\end{array}$ & $\begin{array}{l}\text { Standard } \\
\text { Error } \\
\text { (STERR) }\end{array}$ & $\begin{array}{l}\text { T Statistics } \\
\text { (|O/STERR|) }\end{array}$ & Sig. \\
\hline I1 <- Innovation & 0.758 & 0.750 & 0.047 & 0.047 & 16.154 & 0.000 \\
\hline I2 <- Innovation & 0.813 & 0.816 & 0.035 & 0.035 & 23.445 & 0.000 \\
\hline I3 <- Innovation & 0.642 & 0.644 & 0.070 & 0.070 & 9.147 & 0.000 \\
\hline I4 <- Innovation & 0.642 & 0.639 & 0.071 & 0.071 & 9.021 & 0.000 \\
\hline I5 <- Innovation & 0.698 & 0.697 & 0.051 & 0.051 & 13.558 & 0.000 \\
\hline I6 <- Innovation & 0.690 & 0.683 & 0.073 & 0.073 & 9.438 & 0.000 \\
\hline I7 <- Innovation & 0.670 & 0.664 & 0.058 & 0.058 & 11.528 & 0.000 \\
\hline C1 <- Creativitv & 0.788 & 0.792 & 0.046 & 0.046 & 17.310 & 0.000 \\
\hline C2 <- Creativitv & 0.827 & 0.820 & 0.043 & 0.043 & 19.201 & 0.000 \\
\hline C3 <- Creativitv & 0.730 & 0.730 & 0.047 & 0.047 & 15.589 & 0.000 \\
\hline C4 <- Creativitv & 0.774 & 0.769 & 0.055 & 0.055 & 14.000 & 0.000 \\
\hline C5 <- Creativitv & 0.710 & 0.704 & 0.068 & 0.068 & 10.373 & 0.000 \\
\hline SC1 <- Social Canital & 0.761 & 0.763 & 0.045 & 0.045 & 16.748 & 0.000 \\
\hline SC2 <- Social Canital & 0.766 & 0.754 & 0.066 & 0.066 & 11.593 & 0.000 \\
\hline SC3 <- Social Capital & 0.809 & 0.804 & 0.039 & 0.039 & 20.845 & 0.000 \\
\hline SC4 <- Social Canital & 0.732 & 0.731 & 0.061 & 0.061 & 12.042 & 0.000 \\
\hline E1 <- Green IT Empowerment & 0.776 & 0.756 & 0.069 & 0.069 & 11.305 & 0.000 \\
\hline E2 <- Green IT Empowerment & 0.853 & 0.848 & 0.034 & 0.034 & 24.932 & 0.000 \\
\hline E3 <- Green IT Empowerment & 0.834 & 0.819 & 0.047 & 0.047 & 17.658 & 0.000 \\
\hline E4 <- Green IT Empowerment & 0.782 & 0.768 & 0.070 & 0.070 & 11.102 & 0.000 \\
\hline E5 <- Green IT Empowerment & 0.790 & 0.786 & 0.052 & 0.052 & 15.174 & 0.000 \\
\hline
\end{tabular}

Table 6. Loading factor

Based on the result in Table 6, it can be seen that there are still some items that have an outer loading value $<0.7$; so it is necessary to test the significance of outer loadings. Outer loading significance test shows that all items have a smaller significance level of a (0.05), which indicates that all items have a good convergent validity index. It can also be said that the questionnaire item in this study has a good convergent validity. 


\subsubsection{Reliability Test}

The test result towards reliability can be seen on Cronbach's Alpha while Composite Reliability can be seen in Table 7. Based on Table 6, it can be seen that the values of Cronbach's Alpha and Composite Reliability are greater than 0.7. This indicates that the study variables are reliable (Hair, Anderson, Tathan \& Black, 1995).

\begin{tabular}{|l|c|c|}
\hline Variable & Composite Reliability & Cronbach's Alpha \\
\hline Creativity & 0.877 & 0.825 \\
\hline Green IT Empowerment & 0.903 & 0.866 \\
\hline Innovation & 0.873 & 0.830 \\
\hline Social Capital & 0.851 & 0.770 \\
\hline
\end{tabular}

Table 7. Value of Cronbach's Alpha and Composite Reliability

\subsection{Hypothesis Testing}

The results of hypothesis testing between variables can be seen in Table 8 and Figure 1 .

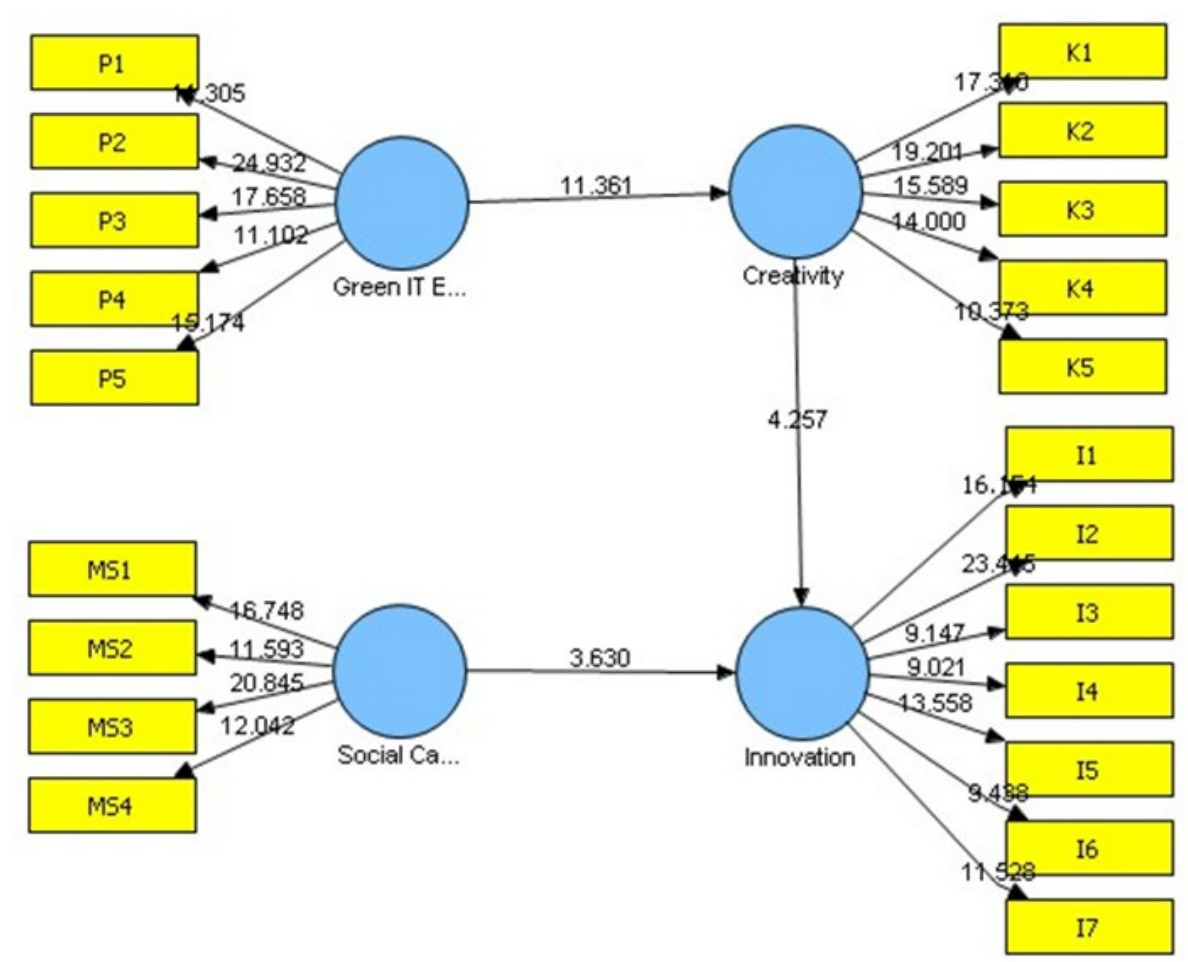

Figure. 1. Result of the Structural Model 


\begin{tabular}{|l|c|c|c|c|}
\hline Path coefficient & T statistics & Original Sample & Sign & Result \\
\hline $\mathrm{H}_{1}:$ Green IT EmD $\rightarrow$ Creat & 11.361 & $0.693^{*}$ & 0.000 & H1 is accepted \\
\hline $\mathrm{H}_{2}:$ Creat $\rightarrow$ Innov & 4.257 & $0.426 *$ & 0.000 & H2 is accedted \\
\hline $\mathrm{H}_{3}:$ Social Cap $\rightarrow$ Innov & 3.630 & $0.367 *$ & 0.000 & H3 is accedted \\
\hline
\end{tabular}

Note: * significant at alpha $5 \%$

Table 8. Path Coefficients

\section{Discussion and Implication}

The study concluded that there was a positive influence of empowerment of Green IT of SMEs to creativity. This also supports the findings of Seibert, et al. (2011) and Çekmecelioğlu and Özbağ (2014), that creativity has a positive effect on innovation (Çekmecelioğlu \& Gunsel, 2013). In Indonesia, Green IT is expected to reduce carbon emissions and also to decrease the effect of global warming. Mariani and Imam (2012) findings concluded generally that from the several aspects examined, the Green IT adoption in Indonesia is still lower compared to Australia, New Zealand and the USA, especially in the aspect of coordinating role for green initiatives defined, the Chief Executive Officers (CEO) plays a leading role in all green (IT and non IT) initiatives, set targets to reduce corporate carbon footprint, responsibilities are clearly defined within each Green IT initiative, IT is responsible for its own electricity costs, and established metrics for assessing the impact of Green IT initiatives. These findings reinforce the need of empowerment of Green IT toward SMEs in Indonesia.

Therefore, some alternative creative empowerments of SMEs in Bantul could be done with the purpose, among others; fostering new entrepreneurs, improving the technical and managerial capabilities, developing quality of services, educating and training, and developing the educational facilities and trainings (Suarja, 2014; Muafi, 2012c). The effort can be done in empowering creative SMEs Green IT, among others: (1) providing awareness about the use of information technology which includes environmental friendly green hardware which include Central Processing Unit (CPU), and memory, green materials, (2) providing awareness about the use of all companies' equipments and household using a wireless connection, (3) turning off all of the CPU and all supporting equipments when they are not in use, (4) using power management features that enable hard disk and display in the "off" position when there is no activity within a few minutes, (5) reducing the use of paper, and other activities that support green IT.

The point is that creative SMEs doers in Bantul, Yogyakarta, are directed to implement sustainable consumption and production efficiently. This empowerment is done to improve the creative innovation of SMEs in generating and producing environmental friendly products. SMEs of batik craftsmen and Vinyl are the examples of products that can be oriented to using 
synthetic natural color by which the raw materials can be derived from plants, roots of trees and natural fibers. Likewise, those producers are also suggested to master different kinds of classical motifs of batik, and not only Yogyakarta's motifs. They are strongly suggested to compete within the markets nationally and globally. Some creative SMEs' businesses are expected to increasingly creative in doing product designs, product quality and product variance. Product designs can be developed while maintaining the local knowledge possessed by each region. The use of information technology will be helpful in enriching the variation of designs and in facilitating the implementation of the production process. Those components are expected to be carried out to achieve the sense of harmony in the field of economic, social and environmental.

Results of the study also concluded that social capital gives effect on innovation. These findings also strengthen the research findings by Camps and Marques (2011) and Kassa (2007). "Paguyuban" and association can also be empowered to strengthen the cooperation network in accessing the information, the adaptation of innovation technology, organizational training, health insurance market, market pricing, access to capital, norms of cooperation and other positive activities. The strong communication and co-operation are needed to be done on a regular basis through activities such as gathering, mutual aid, and community service run by local SMEs. This approves that social capital plays a very strong adhesive to create and produce innovations designed by companies both from the aspect of design, the variance and the quality of the product. Hopefully this research has some implications for the theory and the managerial strategy which soughts: the role of empowerment and social capital which can accelerate the dissemination and implementation of Green IT in order to improve creativity and also creative innovations of SMEs in Bantul, Yogyakarta. "Paguyuban" and association can be useful to strengthen the growth of industrial clusters in a region. Dissemination of information which is closely related to market access, capital, and the adoption of innovative products and processes as well as other positive benefits are greatly needed by SMEs of batik craftsmen. Empowerment can be done regularly by the local or central government, the universities and the community itself.

\section{References}

Achjari, D., Abdilah, W., Suryaningsum, S., \& Supratman (2010). Upaya Peningkatan Daya Saing Masyarakat Berbasis Teknologi Informasi: Studi Pada UMKM Industri Kreatif di DIY (Effort for improving citizen advantage using Technology Information: Study in Creative Small and Medium Enterprise in DIY). Kolokium and Nasional Seminar MSi and Doctorate Program. Faculty of Economics and Business Universitas Gadjah Mada, 167-188. 
Akçomak, I.S., \& Weel, B. (2008). Social Capital, Innovation and Growth: Evidence from Europe. Discussion Paper No. 3341, February, IZA, Germany, 1-58.

Amabile, T.M. (1988). A model of Creativity and Innovation in Organizations. Research in Organizational Behavior, 19, 123-167.

Baron, J.N., \& Hannan, M.T. (1994). The impact of Economy on Contemporary Sociology. Journal of Economic Literature, 32, 1111-1146.

Bourdieu, P. (1983). Forms of capital. In Richards J.C. (Ed.). Handbook of Theory and Research for the Sociology of Education. New York: Greenwood Press.

Camps, S., \& Marques, P. (2011). Social capital and innovation: exploring intra-organisational differences. UAM-Accenture Working Papers, 1-39.

Cekmecelioglu, H.G., \& Gunsel, A. (2013). The effects of individual creativity and organizational climate on firm Innovativeness. Procedia - Social and Behavioral Sciences, 99, 257-264. http://dx.doi.org/10.1016/j.sbspro.2013.10.493

Çekmecelioğlu, H.G., \& Özbağ, G.K. (2014). Linking Psychological Empowerment, Individual Creativity and Firm Innovativeness: A Research on Turkish Manufacturing Industry. Business Management Dynamics, 3(10), 01-13.

Chin, W.W. (1998). The partial least square approach to structural equation modeling. In Marcoulides G.A. (Ed). Modern methods for business research. Mahwah, NJ: Lawrence Erlbaum Associates.

Fors, P., \& Lennerfors, T.T. (2013). Translating Green IT: the case of the Swedish Green IT Audit. Proceedings of the First International Conference on Information and Communication Technologies for Sustainability. ETH Zurich, February 14-16, 208-216.

Grootaert, C., \& Bastelaer, T. (2001). Understanding and measuring social capital: A synthesis of findings and recommendations from the social capital initiative. Social Capital Initiative Working paper, 24. Washington, DC: The World Bank.

Hair, J.F., Anderson, R.E., Tathan, R.L., \& Black W.C. (1995). Multivariate Data Analysis. Fourth Edition. New Jersey: Prentice Hall.

Handayaningsih, S., \& Pujiono, W. (2009). Pembuatan model teknologi informasi paket wisata UKM dalam rangka peningkatan ekonomi kerakyatan. Seminar Nasional Informatika. UPN "Veteran" Yogyakarta, 23 Mei, 94-99. ISSN: 1979-2328.

Hunt, S.D., \& Morgan, R.M. (1995). The comparative advantage theory of competition. Journal of Marketing, 59, 1-15. http://dx.doi.org/10.2307/1252069 
Kaasa, A. (2007). Effects of different Dimensions of social Capital on innovation: Evidence from europe At the regional level. University of Tartu, Faculty of Economics and Business Administration, Narva Road 4-A210. http://dx.doi.org/10.2139/ssrn.976871

Kreitner, R., \& Kinicki, A. (2003). Organizational behavior. 6th Edition. Boston: McGraw-Hill/Irwin.

Mariani, M., \& Imam, K. (2012). A Preliminary Study of Green IT Readiness in Indonesia Organizations. Journal of Energy Technologies and Policy, 2(5), 1-9.

Mawardi, M.J. (2007). Peranan Social Capital dan Pemberdayaan Masyarakat. Komunitas: Jurnal Pengembangan Masyarakat Islam, 2(3), 5-14.

Molla, A., Cooper, V.A., \& Pittayachawan, S. (2009). IT and eco-sustainability: Developing and validating a green IT readiness model. Thirtieth International Conference on Information Systems. Phoenix, 17.

Molla, A., Cooper, V., Corbitt, B., \& Deng, H. (2008). E Readiness to G Readiness: Developing a Green Information Technology Readiness Framework. 19th Australian Conference on Information System, 3-5 Dec, 669-678.

Muafi, Gusaptono, H., Effendi, I., \& Charibaldi, N. (2012a). The Information Technology (IT) Adoption Process and E- Readiness to Use within Yogyakarta Indonesian Small Medium Enterprises (SME). International Journal of Information and Communication Technology Research, 2(1), 29-37.

Muafi (2012c). Pola Hubungan Inovasi Organisasi. People Equity dan Kinerja UKM. Ekuitas, $16(2), 230-243$.

Muafi, \& Roostika, R. (2014). Organizational Performance and Competitive Advantage Determinant of Creative SMEs. European Journal of Economics and Management, 1(2), 7-25.

Muafi, Wahyuningsih, T., Effendi, M.I., \& Sriyono. (2012b). Creating Entrepreneurs through Business Incubator. International Journal of Research in Management \& Technology (IJRMT), 2(4), 463-468.

Murugesan, S. (2008). Harnessing green IT: Principles and practices. IT Pro, January/February, 24-33. http://dx.doi.org/10.1109/MITP.2008.10 
Nahapiet, J., \& Ghoshal, S. (1998). Social Capital, Intellectual Capital, and the Organizational Advantage. The Academy of Management Review, 23(2), 242-266.

http://dx.doi.org/10.2307/259373

Ozturk, A., Umit, K., Medeni, I.T., Ucuncu, B., Caylan, M., Akba, F. et al. (2011). Green ICT (information and communication Technologies): a review of academic and practitioner perspectives. International Journal Of E-business And Egovernment Studies, 3(1), 1-16.

Parkins, D.D., \& Zimerman M.A. (1995). Empowerment, Theory, Research and Application. American Journal of Community Pshicology, 23(5), 569-579. http://dx.doi.org/10.1007/BF02506982

Putnam, R.D. (1995). Bowling Alone: America's Declining Social Capital. Journal of Democracy 6(1), 65-78. http://dx.doi.org/10.1353/jod.1995.0002

Sarosa, S. (2007). The information technology adoption process within Indonesian small and medium enterprises. University of Technology Sydney, Faculty of Information Technology. Thesis, 1-236.

Scott, R.K. (1965). Creative Individual. Academy of Management Journal, 8, 211-219. http://dx.doi.org/10.2307/254789

Seibert, S.E., Wang, G., \& Courtright, S.H. (2011). Antecedents and Consequences of Psychological and Team Empowerment in Organizations: A Meta-Analytic Review. Journal of Applied, 96(5), 981-1003. http://dx.doi.org/10.1037/a0022676

Suarja, W. (2014). Kebijakan pemberdayaan UKM dan koperasi guna Menggerakkan ekonomi rakyat dan Menanggulangi Kemiskinan. http://www.smecda.com/deputi7/file_makalah/IPB-BOGOR.pdf (Accesed: November 2014).

Tenhunen, A. (2011). Conceptualizing and Measuring Green IT Readiness in Finnish Companies. Apllication Area: Elecronic Invoice. Information System Science. Department of Information and Service Economics. Thesis, 1-101.

Tushman, M., \& O'Reilly, C.A. III. (1997). Winning through Innovation: A Practical Guide to Leading Organinizational Change and Renewal. Boston, M.A.: Harvard Business School Press.

Wadwoba, F., Wanyembi, G.W., Omuterema, S., \& Omieno, K.K. (2013). Green ICT Readiness Model for Developing Economies: Case of Kenya. International Journal of Advanced Computer Science adn Application, 4(1), 51-65.

Wahid, F., \& Indarti, N. (2007). Rendah, adopsi TI UKM di Indonesia. Benarkah? Majalah Pusat Informasi Perkoperasian, Dewan Koperasi Indonesia. Edition 281/January/XXIV/2007. http://www.majalah-pip.com/majalah/treeBuilder.php 
Wahyuningsih, T., Muafi, \& Roostika, R. (2014). SMEs Empowerment Through IBPe (Iptek Bagi Produk Ekspor) Grant Program For Vinyl and Natural Fiber Crafts in Bantul Yogyakarta. Australian Journal of Commerce Study, 1(3), 45-50.

Woolcock, M., \& Narayan, D. (2000). Social Capital: Implication for Development Theory. Research and Policy. The World Bank Research Observer, 15(2), 225-249.

http://dx.doi.org/10.1093/wbro/15.2.225

Yuniarti, D. (2012). Studi Kesiapan Industri TIK Dalam Negeri Untuk Mendukung Implementasi Green ICT Pada Sektor Telekomunikasi, http://balitbang.kominfo.go.id/balitbang/sdppi/2014/03/10/diahyuniarti-s-t-m-eng/

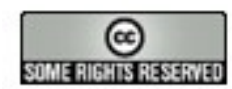

Article's contents are provided on a Attribution-Non Commercial 3.0 Creative commons license. Readers are allowed to copy, distribute and communicate article's contents, provided the author's and Journal of Industrial Engineering and Management's names are included. It must not be used for commercial purposes. To see the complete license contents, please visit http://creativecommons.org/licenses/by-nc/3.0/. 